Article

\title{
Supercritical Transesterification of Palm Oil and Hydrated Ethanol in a Fixed Bed Reactor with a $\mathrm{CaO} / \mathrm{Al}_{2} \mathrm{O}_{3}$ Catalyst
}

\author{
Ruengwit Sawangkeaw ${ }^{1}$, Pornicha Tejvirat ${ }^{1}$, Chawalit Ngamcharassrivichai ${ }^{1,2}$ and \\ Somkiat Ngamprasertsith ${ }^{1,2, *}$
}

1 Fuels Research Center, Department of Chemical Technology, Faculty of Science, Chulalongkorn University, 254 Phayathai Road, Pathumwan, Bangkok 10330, Thailand;

E-Mails: r_sawangkeaw@yahoo.com (R.S.); sodamag_yoshirin@hotmail.com (P.T.); chawalit.n@chula.ac.th (C.N.)

2 Center of Excellence on Petrochemical and Materials Technology, Chulalongkorn University, 254 Phayathai Road, Pathumwan, Bangkok 10330, Thailand

* Author to whom correspondence should be addressed; E-Mail: somkiat.n@chula.ac.th; Tel.: +66-2218-7678; Fax: +66-2255-5831.

Received: 11 January 2012; in revised form: 2 April 2012 / Accepted: 6 April 2012 /

Published: 19 April 2012

\begin{abstract}
Biodiesel production from palm oil and hydrated ethanol in a fixed bed reactor using $\mathrm{CaO} / \mathrm{Al}_{2} \mathrm{O}_{3}$ as the catalyst was investigated and optimized using response surface methodology. The investigated parameters were temperature, pressure, ethanol $/ \mathrm{palm}$ oil molar ratio, residence time and total mass flow rate. The approach was divided into two parts, a preliminary study using broad scale changes over a reasonable range of the above operating parameters and then, using this data to select a narrower range, a finer scale study to optimize the selected narrower operating parameters from the preliminary study. The resultant biodiesel obtained under the optimal conditions $\left(285{ }^{\circ} \mathrm{C}, 20 \mathrm{MPa}, 30: 1\right.$ ethanol/oil molar ratio, $2 \mathrm{~g} / \mathrm{min}$ flow rate and $4.85 \mathrm{~min}$ residence time) was measured for 11 fuel properties following the International Biodiesel Standard (EN14214), and was found to comply with this International Standard. Moreover, $\mathrm{ZnO} / \mathrm{Al}_{2} \mathrm{O}_{3}$ and $\mathrm{La}_{2} \mathrm{O}_{3} / \mathrm{Al}_{2} \mathrm{O}_{3}$ catalysts were tested for their activity and stability. Although the $\mathrm{La}_{2} \mathrm{O}_{3} / \mathrm{Al}_{2} \mathrm{O}_{3}$ catalyst had a slightly higher initial activity than that of $\mathrm{CaO} / \mathrm{Al}_{2} \mathrm{O}_{3}$, it is some 800 -fold more expensive. Therefore, the $\mathrm{CaO} / \mathrm{Al}_{2} \mathrm{O}_{3}$ catalyst has a greater industrial potential than $\mathrm{La}_{2} \mathrm{O}_{3} / \mathrm{Al}_{2} \mathrm{O}_{3}$, when comparing together the technical and economic benefits.
\end{abstract}


Keywords: biodiesel; fuel properties; hydrated ethanol; supercritical transesterification; calcium oxide

\section{Introduction}

The dwindling supplies in the long term and the escalating price of petroleum and emission of greenhouse gases in the short and long terms are increasingly serious problems for many countries, driving an interest in renewable fuels as a long-term solution for the sustainable future. Biodiesel, a mono alkyl ester of long chain fatty acids, is one of the renewable fuels currently of interest, being derived from renewable oil-based biomass, including waste oils, via esterification and/or transesterification reactions with small chain alcohols, such as methanol and ethanol. To date the studies on biodiesel production have mostly focused on methanol to form fatty acid methyl esters (FAME), despite the fact that methanol is currently produced primarily from non-renewable sources, such as natural gas. On the other hand, ethanol can be manufactured in many countries from agricultural (waste) products via fermentation. However, research using ethanol as the biodiesel feedstock to create fatty acid ethyl esters (FAEE) is currently largely lacking, in part due to the fact that absolute (dry) ethanol is required for the conventional basic catalytic process and its price is not economically competitive compared to that for methanol.

Supercritical transesterification, or biodiesel production in supercritical alcohols (SCA), has many advantages over conventional catalytic processes, especially in feedstock flexibility, as summarized elsewhere [1-5]. Furthermore, it was reported that hydrated ethanol [5\% (v/v) water content] could still be employed for supercritical transesterification [6,7]. Since hydrated ethanol has a lower price than absolute ethanol, it could make the FAEE based biodiesel production process more feasible and economically similar to that which uses methanol as feedstock for FAME production. However, the optimal parameters for biodiesel production in SCA are a high pressure (19-45 MPa), a high temperature $\left(320-350{ }^{\circ} \mathrm{C}\right.$ ) and a high alcohol to oil ratio $(40: 1-42: 1)$ [8-10]. To reduce these parameters, and so reduce the environmental and economic costs of biodiesel production by the SCA system, the addition of a suitable heterogeneous catalyst is an attractive idea.

Of all the metal oxides, calcium oxide $(\mathrm{CaO})$ has been reported as a cheap, stable and effective catalyst for the transesterification of vegetable oils with methanol at ambient pressure [11-14]. Furthermore, FAME biodiesel production in supercritical methanol (SCM) in the presence of a $\mathrm{CaO}$ catalyst in a batch reactor revealed the higher catalytic activity of $\mathrm{CaO}$ under supercritical conditions than at an ambient pressure [15]. For example, the highest FAME content was obtained at $\sim 1.5 \mathrm{~h}$ at ambient pressure [13], while it was achieved within only $8.33 \mathrm{~min}$ at supercritical conditions [15]. However, research on FAEE biodiesel production, as opposed to that for FAME production, from vegetable oils and ethanol using $\mathrm{CaO}$ as the catalyst is scarce.

This work aimed to investigate the effects of temperature, pressure, ethanol/palm oil molar ratio and residence time on FAEE biodiesel production in supercritical ethanol (SCE) using $\mathrm{CaO} / \mathrm{Al}_{2} \mathrm{O}_{3}$ as a heterogeneous catalyst. Since the experiments were conducted in a fixed bed reactor, a supporting alumina ball $\left(\mathrm{Al}_{2} \mathrm{O}_{3}\right)$ was added to avoid a channeling of the catalyst bed and to improve the 
mechanical properties of the $\mathrm{CaO}$ catalyst. Moreover, this work employed hydrated ethanol $[5.5 \%(\mathrm{v} / \mathrm{v})$ water] as the feedstock to demonstrate the advantage and feasibility of biodiesel production in SCE with feedstock flexibility. With respect to the metal oxide composition of the heterogonous catalyst, alumina supported zinc $\left(\mathrm{ZnO} / \mathrm{Al}_{2} \mathrm{O}_{3}\right)$ and lanthanum $\left(\mathrm{La}_{2} \mathrm{O}_{3} / \mathrm{Al}_{2} \mathrm{O}_{3}\right)$ oxides were also tested as suitable catalysts at the optimal conditions for the $\mathrm{CaO} / \mathrm{Al}_{2} \mathrm{O}_{3}$ catalyst.

\section{Experimental Section}

\subsection{Catalyst Preparation}

Catalysts were prepared according to the incipient-wetness impregnation of aqueous solutions on an activated alumina ball support. The alumina ball (1-2 mm diameter) was supplied by Nicho, whilst the metal salt precursors, $\mathrm{Ca}\left(\mathrm{NO}_{3}\right)_{2} \cdot 4 \mathrm{H}_{2} \mathrm{O}(99 \%), \mathrm{Zn}\left(\mathrm{NO}_{3}\right)_{2} \cdot 6 \mathrm{H}_{2} \mathrm{O}(98.5 \%)$ and $\mathrm{La}\left(\mathrm{NO}_{3}\right)_{3} \cdot 6 \mathrm{H}_{2} \mathrm{O}(99 \%)$, were purchased from Rankem, Qrec and Ajex Chemical, respectively. The required amount of metal nitrate precursor solution was prepared by completely dissolving the metal nitrates in water at ambient temperature, and then gently adding to the support and vigorously mixing at room temperature for $2 \mathrm{~h}$. The resultant paste was then rotary evaporated (Heidolph Co. Ltd., model 4003) at $80{ }^{\circ} \mathrm{C}$ for $1 \mathrm{~h}$ to partially remove the water and finally the wet paste was dried in oven at $100{ }^{\circ} \mathrm{C}$ for $24 \mathrm{~h}$ and then calcined in a muffle furnace at $550{ }^{\circ} \mathrm{C}$ for $2 \mathrm{~h}$, cooled and stored in a desiccator until use.

\subsection{Catalyst Characterization}

Elemental analysis of the catalysts was performed by energy dispersive X-ray fluorescence (XRF) spectrometry on a Siemens Co. Ltd., model PE 2400. The crystallinity of the supports and catalysts was analyzed by powder X-ray diffraction (XRD) using a Bruker Co. Ltd., model D8 Discover. The contaminated organic compounds on the used catalyst were measured by thermogravimetric analysis (TGA) on a model Pyris Diamond thermogravimetric analyzer from Perkin Elmer Co. Ltd.

\subsection{Transesterification Apparatus and Procedure}

The schematic diagram of the fixed bed reactor, with the two different feedstock delivery systems used, is shown in Figure 1. For the initial preliminary study, palm oil and ethanol were delivered separately into the reactor by two high-pressure pumps (Thar Technology Co. Ltd., model P200 and P50) (Figure 1a) that were able to provide a stable and controllable flow rate of from approximately of 2 and $1 \mathrm{~g} / \mathrm{min}$ upwards for the palm oil and ethanol, respectively. In this preliminary study, the optimal condition was found at a flow rate of less $3 \mathrm{~g} / \mathrm{min}$. Thus, the reactants delivery system was modified to use a single pump (Thar Technology Co. Ltd., model P50) to deliver a premixed ethanol: oil feedstock (Figure 1b). In this set up the palm oil and ethanol mixer was a 500-mL Erlenmeyer flask with an overhead stirrer (BEC Thai Co. Ltd., KW20N) equipped with a four-blade turbine to homogenize the oil/ethanol mixture at $350 \mathrm{rpm}$. In both preliminary and optimization studies, the reaction mixture flowed through a coiled pre-heater (SUS316, $3.18 \mathrm{~mm}$ o.d., $0.61 \mathrm{~mm}$ thickness and $1.5 \mathrm{~m}$ length) into the fixed bed reactor (SUS316, $12.70 \mathrm{~mm}$ o.d., $2.11 \mathrm{~mm}$ thickness and $0.53 \mathrm{~m}$ height). The reactor was heated by an electrical tubular furnace (Lenton Co. Ltd., model 2416CG) with the temperature controlled at the upper, center and lower regions of the furnace. The inlet and outlet of the fixed bed 
reactor were packed with inert alumina balls to ensure the exactness of residence time due to the fact that the temperature at those points was lower than the actual reacting temperature. The supported catalysts weight in the fixed bed reactor was kept constant at $20 \mathrm{~g}$ for all experiments. Furthermore, the temperature at the outlet of the reactor was monitored in-real time by a k-type thermocouple. The reacted sample flowed inwards into a double-pipe heat exchanger, an inline filter (Swagelok Co. Ltd., model SS-2F-0.5, pore size $0.5 \mu \mathrm{m}$ ) and a back-pressure regulator (Swagelok Co. Ltd., model Z85943001), respectively. The system pressure was measured by two pressure gauges (Swagelok Co. Ltd., model EN 837-1), one at the high-pressure pump and one just before the entrance of the back-pressure regulator.

Figure 1. Schematic diagram of the experimental apparatus showing the reactants delivery system for (a) the preliminary experiments and (b) the optimization, catalysts durability and reusability studies.

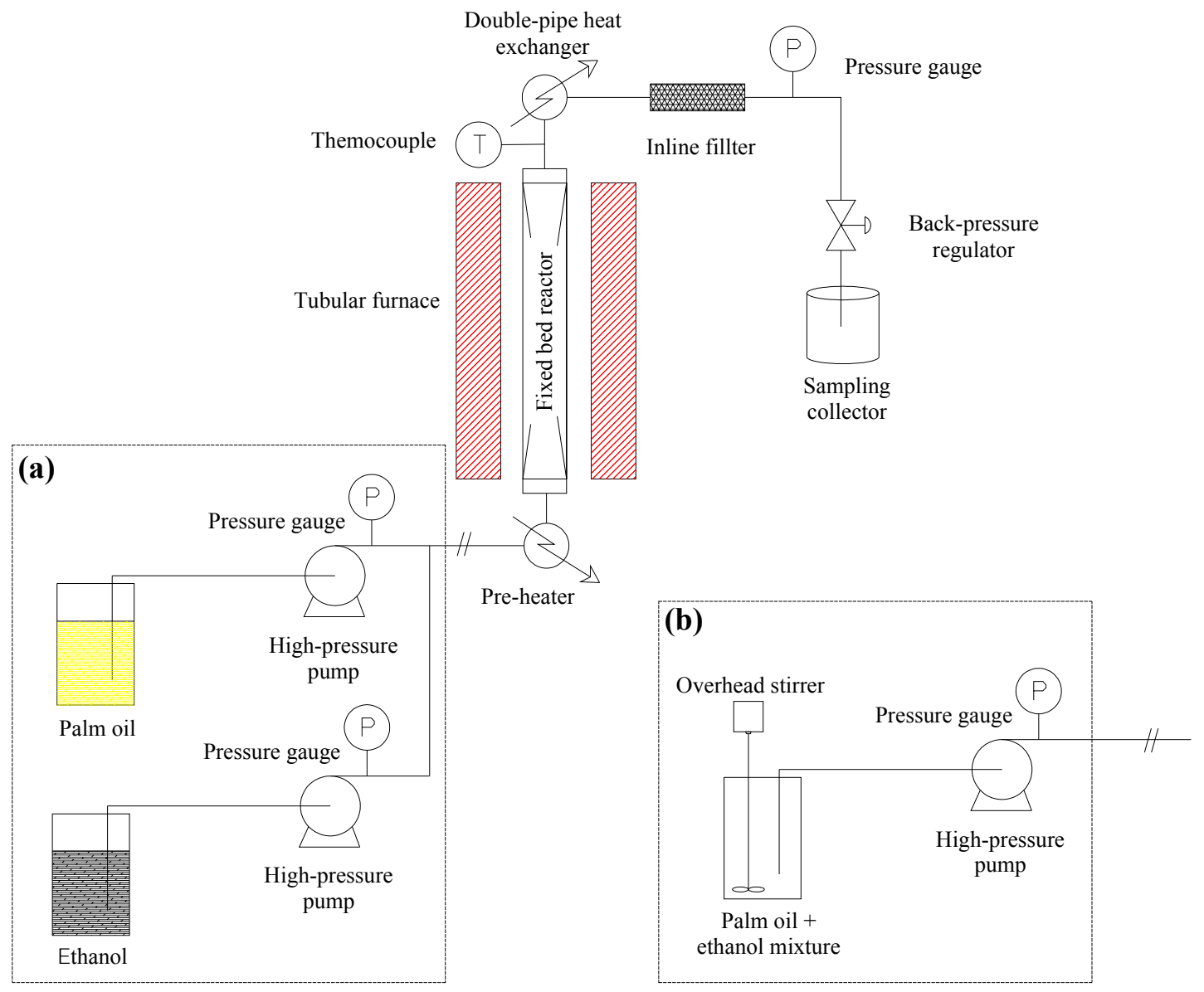

For the initial preliminary study, refined palm olein oil (edible grade, supplied by Morakot Industries Co., Ltd.) and hydrated ethanol [94.5\% (v/v), supplied by a local distributor] were fed separately at the desired ethanol/oil molar ratio while, for the later optimization study, the refined palm olein oil and hydrated ethanol were mixed at $350 \mathrm{rpm}$ before being pumped into the reactor. In either case, the ethanol-oil mixture was measured at the reactor column inlet as the total mass flow rate by the weighing and timing method, and then was fed into the fixed bed reactor. The tubular furnace was turned on and the heater temperature adjusted to obtain the desired outlet temperature. For example, the center heater temperature was set at $300{ }^{\circ} \mathrm{C}$ to obtain an outlet temperature of $280{ }^{\circ} \mathrm{C}$. After the 
measured inlet and outlet flow rate were approximately equal, the system pressure was gently increased by closing the back-pressure regulator. When the pressure was observed to be constant, the biodiesel products were sampled at $15 \mathrm{~min}$ intervals for the first hour and then at $30 \mathrm{~min}$ intervals for the next hour to measure the $\%(\mathrm{w} / \mathrm{w})$ FAEE content. The steady state was defined as when a nearly constant \% (w/w) FAEE content was observed over three successive sampling points. Before the samples were analyzed, they were enriched for FAEE by evaporating the excess ethanol away in a rotary evaporator and then centrifugation $(3000 \mathrm{rpm}, 10 \mathrm{~min})$ based phase separation to remove the glycerol.

\subsection{Biodiesel Sample Analysis}

The FAEE content in biodiesel samples was measured by gas chromatography (GC) on a Varian Model CP-3800 equipped with a capillary column (30 m, DB-1ht, J\&W Scientific) and a flame ionization detector. A known amount of the biodiesel sample and an internal standard, methyl heptadecanoate, were diluted with $n$-heptane before injection and standardized following the EN 14103 method. The $\%(w / w)$ FAEE content was defined as the ratio of the weight of FAEE in the ester phase obtained from $\mathrm{GC}$ to the total weight of the biodiesel sample.

For the GC-mass spectrometry (GC-MS) based analysis, a Shimadzu Model QP2010 instrument equipped with a capillary column $(30 \mathrm{~m}$ length $\times 0.25 \mathrm{~mm}$ o.d. $\times 0.25 \mu \mathrm{m}$ film thickness, DB-5 ms, J\&W Scientific) was used with helium as the carrier gas. The molecular weight scan range was $50-850 \mathrm{~m} / \mathrm{z}$ with a $3 \mathrm{~min}$ solvent cut time. The injection port, ion source and interface temperature were 250,200 and $230{ }^{\circ} \mathrm{C}$, respectively. The column was held at $50{ }^{\circ} \mathrm{C}$ for $5 \mathrm{~min}$, and then the temperature was increased to $200^{\circ} \mathrm{C}$ at $15^{\circ} \mathrm{C} / \mathrm{min}$ and held at $200{ }^{\circ} \mathrm{C}$ for $45 \mathrm{~min}$.

The biodiesel sample that was obtained from the optimal conditions was analyzed for its fuel properties by the international organization for standardization (ISO) testing methods, including the density at $15{ }^{\circ} \mathrm{C}$ (ISO 3675:1998), viscosity at $40{ }^{\circ} \mathrm{C}$ (EN ISO 3104:1994), cetane index (ISO 4264:2007), acid value (EN 14104:2003), strip copper corrosion (ASTM D130), flash point (ISO 2719:2002), pour point (ISO 3016:1994), glycerides content (EN 14105) and distillation characteristics (ISO 3405:2011). All tests were performed under the ISO/IEC 17025 standard at the fuel testing laboratory in the quality control division of the PTT Public Company Limited, Phrakhanong Oil Terminal, Bangkok, Thailand.

\subsection{Experimental Design for Optimization Study}

After the preliminary experiments provided the narrower ranges for each evaluated parameter, a rotatable central composite design (CCD) $[16,17]$ was adapted to evaluate the effect of the operating temperature $\left(240-280^{\circ} \mathrm{C}\right)$, pressure $(8.0-20.0 \mathrm{MPa})$, total mass flow rate $(2-4 \mathrm{~g} / \mathrm{min})$ and ethanol: palm oil molar ratio (18:1-30:1) on the resulting FAEE content. These four operating parameters were chosen and their appropriated ranges were selected based upon the preliminary studies, as detailed in the results Section 3.1. The experiments were performed in duplicate at non-center points (factorial and axial points) and triplicate at the center point, thus totaling 43 runs. All experiments were run in a random order. The optimal conditions were then calculated by the regression model and consequently verified experimentally (within the limitation of the high pressure pumps). 
The residence time was excluded from the CCD factors to allow for the independent assumption in the ANOVA [16,17]. This is because the residence time could not be evaluated as a separate factor in the CCD due to the fact that it is an implicit dependent variable. For instance, the residence time can be estimated from the total mass flow rate and the density of the reaction mixture, but these are functions of the ethanol:palm oil molar ratio and of the temperature and pressure, respectively.

However, the effects of the residence time on the \% (w/w) FAEE content was interpreted in the preliminary study (Section 3.1). In this work, we calculated the residence time $(\tau$, min) using Equation (1):

$$
\tau=\frac{V}{\frac{\dot{m_{e}}}{\rho^{\prime}{ }_{e}}+\frac{\dot{m_{o}}}{\rho^{\prime}{ }_{o}}}
$$

where $V$ is the reactor volume $\left(\mathrm{cm}^{3}\right)$, which is subtracted by the bed volume, $m$ is the mass flow rate ( $\mathrm{g} / \mathrm{min})$ at ambient conditions and $\rho^{\prime}$ is the density $\left(\mathrm{g} / \mathrm{cm}^{3}\right)$ of pure substance at the reaction conditions. The subscripts $e$ and $o$ indicate that parameter for ethanol and palm oil, respectively. The density of hydrated ethanol (95.5\%) at elevated temperatures and pressures was taken from the literature [18], while the density of palm oil is assumed to be a linear function of temperature only [19].

\section{Results and Discussion}

\subsection{The Preliminary Study}

\subsubsection{Effects of Temperature on the FAEE Content}

The effects of temperature were initially investigated using $\mathrm{Al}_{2} \mathrm{O}_{3}$ as blank test and $\mathrm{CaO} / \mathrm{Al}_{2} \mathrm{O}_{3}$ as the catalyst in range of $220-320^{\circ} \mathrm{C}$. The experiments were conducted at a constant ethanol $/ \mathrm{palm}$ oil molar ratio of $26: 1$, pressure of $20 \mathrm{MPa}$ and total mass flow rate of $6.2 \mathrm{~g} / \mathrm{min}$.

Figure 2. The $\%(\mathrm{w} / \mathrm{w})$ FAEE content as function of the temperature for the SCE transesterification of palm oil at $20 \mathrm{MPa}$, an ethanol/palm oil molar ratio of 26:1, a total mass flow rate of $6.2 \mathrm{~g} / \mathrm{min}$ and a residence time of $1.02 \mathrm{~min}$. Data are shown as the mean $+1 \mathrm{SD}$ and are derived from two or three independent replicates.

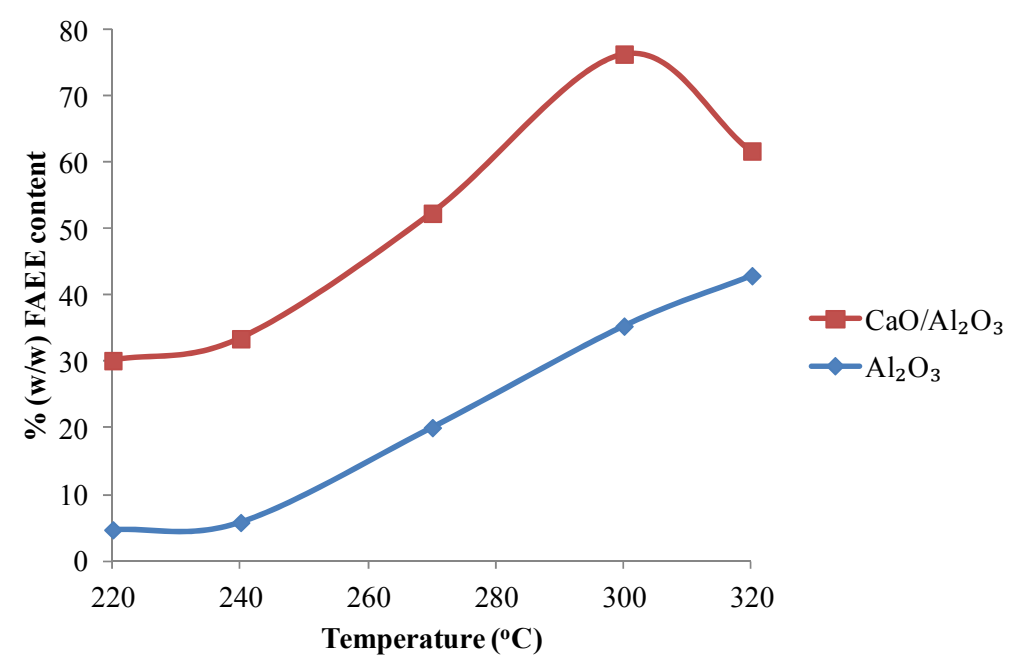


The \% (w/w) FAEE content when the SCE process was performed in the presence of the $\mathrm{CaO} / \mathrm{Al}_{2} \mathrm{O}_{3}$ catalyst was clearly higher than that of the catalyst-free case $\left(\mathrm{Al}_{2} \mathrm{O}_{3}\right)$, especially at low temperatures (Figure 2). However, whilst the \% (w/w) FAEE content was observed to continuously increase with increasing temperature in the catalyst-free case, in contrast with the $\mathrm{CaO} / \mathrm{Al}_{2} \mathrm{O}_{3}$ catalyst it reached a maximal value at around $300{ }^{\circ} \mathrm{C}$ and then decreased at higher temperatures. Since $\mathrm{CaO}$ is proposed to be catalytic for the cracking of vegetable oils to biofuel [20,21], the lowered \% (w/w) FAEE content seen with the $\mathrm{CaO} / \mathrm{Al}_{2} \mathrm{O}_{3}$ catalyst at higher temperatures is likely to be due to the partial cracking of unsaturated fatty acids at $320{ }^{\circ} \mathrm{C}$. This notion is supported by the total ions chromatogram from the GC-MS analysis of the biodiesel sample obtained at $320{ }^{\circ} \mathrm{C}, 20 \mathrm{MPa}$ and a $26: 1$ of ethanol/palm oil molar ratio with $\mathrm{CaO} / \mathrm{Al}_{2} \mathrm{O}_{3}$ as the catalyst, where the numerous small peaks appearing with a retention time of less than 15 min represents the low molecular weight hydrocarbon $\left(\mathrm{C}_{4}-\mathrm{C}_{11}\right)$, fatty acid and ester products from catalytic cracking (Figure 3 and Table 1$)$. Therefore, the maximum temperature for this optimization study was set at $280{ }^{\circ} \mathrm{C}$ to avoid the effects of thermal degradation, and the minimum at $240{ }^{\circ} \mathrm{C}$ as below that temperature was ineffective.

Figure 3. The total ion GC-MS chromatogram of the biodiesel sample obtained at $320{ }^{\circ} \mathrm{C}$, $20 \mathrm{MPa}$, an ethanol:palm oil molar ratio of $26: 1$, a total mass flow rate of $6.2 \mathrm{~g} / \mathrm{min}$ and a residence time of $1.02 \mathrm{~min}$ with a $\mathrm{CaO} / \mathrm{Al}_{2} \mathrm{O}_{3}$ catalyst. Chromatograph shown is representative of that seen from two independent repeats.

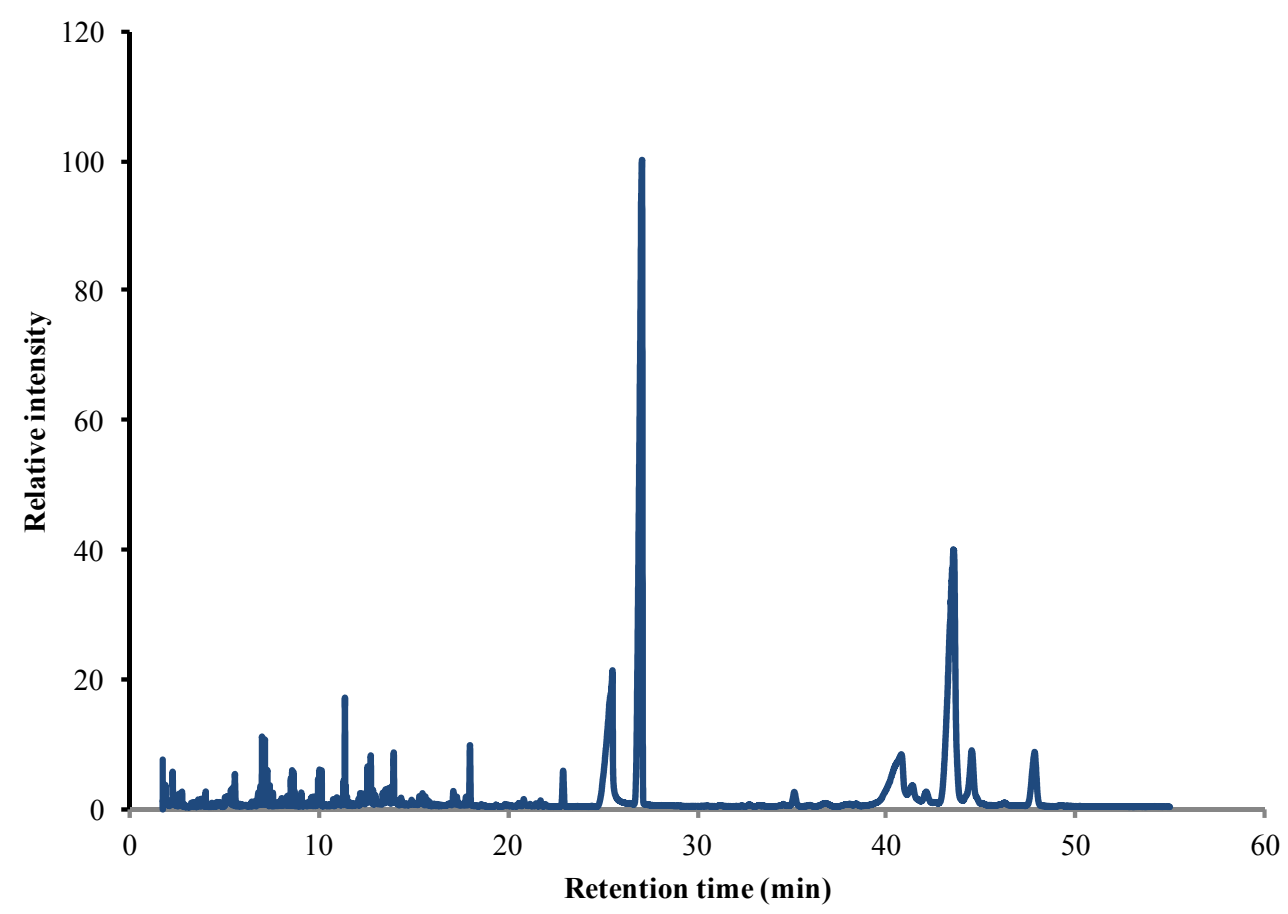

\subsubsection{Effect of Pressure on the $\%(w / w)$ FAEE Content}

The effects of pressure on the SCE production of FAEE was studied at $300{ }^{\circ} \mathrm{C}$, a $26: 1$ of ethanol/palm oil molar ratio and total mass flow rate of $6.2 \mathrm{~g} / \mathrm{min}$. The FAEE content slightly increased with rising pressure both in the absence $\left(\mathrm{Al}_{2} \mathrm{O}_{3}\right)$ and presence of the $\mathrm{CaO} / \mathrm{Al}_{2} \mathrm{O}_{3}$ catalyst (Figure 4). 
Table 1. The assignment of selected peaks in Figure 3.

\begin{tabular}{|c|c|c|}
\hline Peak $^{\#}$ & Retention time (min) & Name \\
\hline 1 & 2.60 & Butanoic acid \\
\hline 2 & 5.36 & 5-Hexenoic acid \\
\hline 3 & 5.57 & Ethyl hexanoate \\
\hline 4 & 6.80 & 3-Heptenoic acid \\
\hline 5 & 6.92 & Heptanoic acid \\
\hline 6 & 7.00 & Ethyl 6-heptenoate \\
\hline 7 & 7.06 & 1-Undecene \\
\hline 8 & 7.15 & Ethyl heptanoate \\
\hline 9 & 7.28 & 5-Undecene \\
\hline 10 & 8.53 & Ethyl 7-octenoate \\
\hline 11 & 8.59 & 1-Tridecene \\
\hline 12 & 8.67 & Ethyl octanoate \\
\hline 13 & 9.97 & Ethyl 8-nonenoate \\
\hline 14 & 10.04 & 1-Tridecene \\
\hline 15 & 10.09 & Ethyl nonanoate \\
\hline 16 & 10.15 & Pentadecane \\
\hline 17 & 11.31 & Ethyl 9-decenoate \\
\hline 18 & 11.38 & 1-Pentadecene \\
\hline 19 & 12.19 & Cyclopentene \\
\hline 20 & 12.34 & 3-Hexyl-1-cyclohexene \\
\hline 21 & 12.58 & Ethyl undecenoate \\
\hline 22 & 12.65 & 1-Pentadecene \\
\hline 23 & 12.75 & Pentadecane \\
\hline 24 & 13.53 & Dodecanoic acid \\
\hline 25 & 13.68 & 5-Tetradecen-1-ol \\
\hline 26 & 13.97 & Ethyl dodecanoate \\
\hline 27 & 15.49 & Ethyl 9-hexadecenoate \\
\hline 28 & 17.12 & Tetradecanoic acid \\
\hline 29 & 17.30 & 9-Octadecen-1-ol \\
\hline 30 & 17.99 & Ethyl tetradecanoate \\
\hline 31 & 22.92 & Methyl hexadecanoate \\
\hline 32 & 25.52 & Hexanoic acid \\
\hline 33 & 27.09 & Ethyl hexadecanoate \\
\hline 34 & 35.14 & Methyl 9-octadecenoate \\
\hline 35 & 40.80 & cis-9-Octadecenoic acid \\
\hline 36 & 41.40 & cis-9-Hexadecenal \\
\hline 37 & 42.12 & Ethyl 9,12-octadecadienoate \\
\hline 38 & 43.58 & Ethyl 9-octadecenoate \\
\hline 39 & 44.54 & 3,13-Octadecedien-1-ol \\
\hline 40 & 47.85 & Ethyloctadecanoate \\
\hline
\end{tabular}

This is probably because the experimental pressure range was higher than the critical pressure of ethanol $(6.3 \mathrm{MPa})$, and so the density of the reaction mixture, which is related to the residence time, was slightly enhanced when the operating pressure was above 6.3 MPa accordingly. Therefore, a 
pressure range of between $8.0 \mathrm{MPa}$ (slightly above the critical pressure of ethanol) and $20.0 \mathrm{MPa}$ (the maximum operating pressure of the system) was selected for further evaluation.

Figure 4. The $\%(\mathrm{w} / \mathrm{w})$ FAEE content as function of the reaction pressure for the SCE transesterification of palm oil at $300{ }^{\circ} \mathrm{C}$, an ethanol:palm oil molar ratio of $26: 1$, a total mass flow rate of $6.2 \mathrm{~g} / \mathrm{min}$ and a residence time of $1.02 \mathrm{~min}$. Data are shown as the mean $\pm 1 \mathrm{SD}$ and are derived from two or three independent replicates.

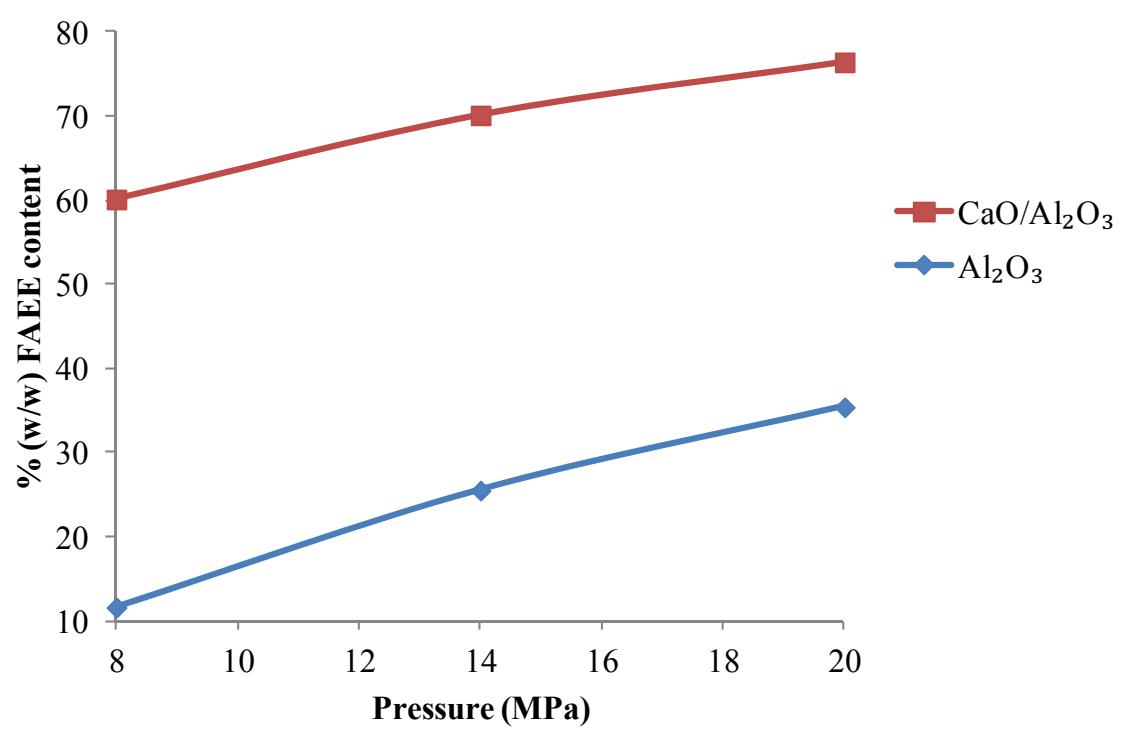

\subsubsection{Effects of the Ethanol/Palm Oil Molar Ratio on the \% (w/w) FAEE Content}

Since the critical properties of the reaction mixture and mass transfer limitation depend on the ethanol/palm oil molar ratio, the effects of the ethanol/palm oil molar ratio on the FAEE content was evaluated (Figure 5). The \% (w/w) FAEE content initially increased as the ethanol/oil molar ratio increased up to a maximum at a $34: 1$ of ethanol/palm oil molar ratio, and then either leveled off (no catalyst) or decreased slightly $\left(\mathrm{CaO} / \mathrm{Al}_{2} \mathrm{O}_{3}\right.$ catalyst) as the ethanol/oil molar ratio increased further to 50:1. At a low ethanol/palm oil molar ratio, the formation of adsorbed ethoxide on the $\mathrm{CaO}$ surface would be retarded due to the small contact area between $\mathrm{CaO}$ and ethanol [11]. Moreover, the nucleophilic reaction of SCE requires a higher temperature for completion of the reaction. On the other hand, too high an ethanol/palm oil molar ratio provided no significant increase in the \% (w/w) FAEE content due to the dilution effect of the reactants and the reduction of the residence time. For instance, the triglycerides could be sterically blocked from the ethoxide or nucleophilic attack by the presence of ethanol molecule(s). Thus, an ethanol/palm oil molar ratio of 18:1-30:1 was selected for the subsequent optimization study.

\subsubsection{Effect of the Residence Time on the \% (w/w) FAEE Content}

Decreasing the residence time dramatically decreased the \% (w/w) FAEE content (Figure 6). According to the results of the initial broad scale preliminary study (sections 3.1.1-3.1.3), the \% (w/w) FAEE content could be enhanced by increasing the reaction temperature, pressure and ethanol/palm oil molar ratio. However, too high an ethanol/palm oil molar ratio decreased the FAEE content because 
the density of reaction mixture was sharply increased and resulted in a lowered residence time. In addition, the reaction temperature and pressure were limited to a maximum of $300^{\circ} \mathrm{C}$ and $20 \mathrm{MPa}$ due to the negative effect of thermal cracking and the working pressure of the reactor, respectively. Therefore, a residence time of less than $2.11 \mathrm{~min}$ was required to achieve the complete SCE transesterification reaction. The residence time was transformed to the total mass flow rate using Equation (1) because it could not be included as a CCD factor as mentioned in section 2.5. Since the calculated total mass flow rate was lower than $3.0 \mathrm{~g} / \mathrm{min}$, the reactants delivery system was modified as mentioned in section 2.3 (Figure 1b).

Figure 5. The $\%(\mathrm{w} / \mathrm{w})$ FAEE content as function of the ethanol:palm oil molar ratio for the SCE transesterification of palm oil at $300{ }^{\circ} \mathrm{C}, 20 \mathrm{MPa}$, a total mass flow rate of $6.2 \mathrm{~g} / \mathrm{min}$ and a residence time of $1.02 \mathrm{~min}$. Data are shown as the mean $+1 \mathrm{SD}$ and are derived from two or three independent replicates.

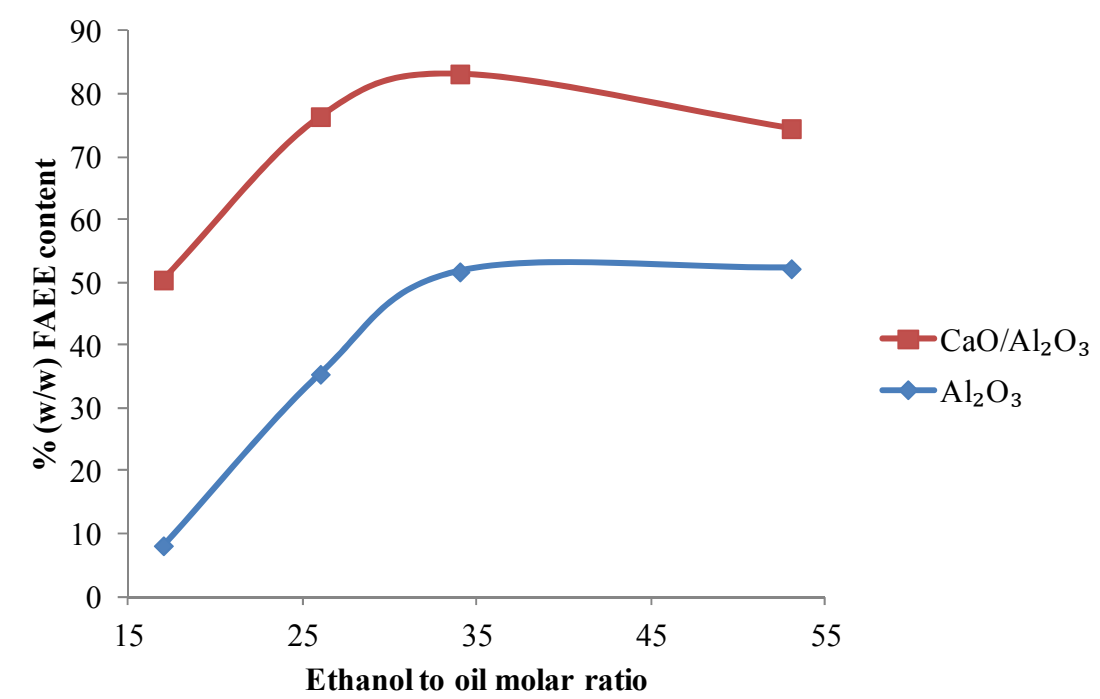

Figure 6. The $\%(\mathrm{w} / \mathrm{w})$ FAEE content as a function of the residence time for the SCE transesterification of palm oil at $300{ }^{\circ} \mathrm{C}, 20 \mathrm{MPa}$ and an ethanol/palm oil molar ratio of 26:1. Data are shown as the mean $\pm 1 \mathrm{SD}$ and are derived from two or three independent replicates.

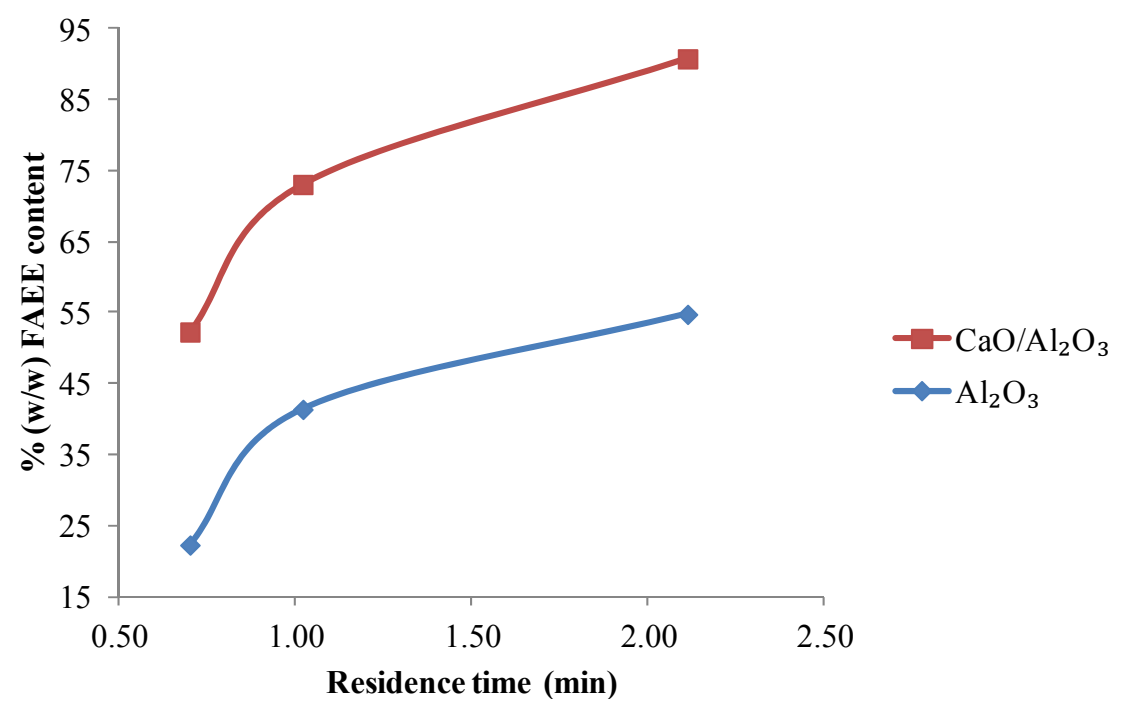




\subsection{The Optimization Study}

The results from CCD and the ANOVA, which were evaluated using the Design-Expert ${ }^{\circledR}$ 7, Trial version (State Ease Inc., Minneapolis, MN, USA), are summarized in Tables 2 and 3, respectively.

Table 2. The experimental conditions from the CCD and observed $\%(w / w)$ FAEE content.

\begin{tabular}{|c|c|c|c|c|c|}
\hline Run order & $\begin{array}{c}\text { Temperature } \\
\left({ }^{\circ} \mathrm{C}\right)\end{array}$ & $\begin{array}{l}\text { Pressure } \\
(\mathrm{MPa})\end{array}$ & $\begin{array}{l}\text { Total mass flow rate } \\
(\mathrm{g} / \mathrm{min})\end{array}$ & $\begin{array}{l}\text { EtOH:Oil } \\
\text { (mol ratio) }\end{array}$ & $\begin{array}{l}\text { FAEE } \\
\%(w / w)\end{array}$ \\
\hline 3 & 238 & 8.12 & 2.01 & 18 & 42.8 \\
\hline 26 & 243 & 8.42 & 1.99 & 18 & 46.4 \\
\hline 24 & 284 & 8.18 & 2.00 & 18 & 59.4 \\
\hline 37 & 280 & 7.88 & 2.05 & 18 & 53.7 \\
\hline 41 & 241 & 20.00 & 2.02 & 18 & 56.1 \\
\hline 14 & 242 & 19.82 & 2.01 & 18 & 54.0 \\
\hline 11 & 285 & 20.72 & 1.99 & 18 & 66.3 \\
\hline 29 & 284 & 20.42 & 2.02 & 18 & 69.0 \\
\hline 16 & 262 & 14.00 & 3.06 & 18 & 15.8 \\
\hline 36 & 238 & 7.82 & 4.03 & 18 & 7.5 \\
\hline 21 & 240 & 8.12 & 4.01 & 18 & 7.0 \\
\hline 10 & 283 & 8.42 & 3.98 & 18 & 48.4 \\
\hline 34 & 278 & 8.12 & 4.02 & 18 & 49.0 \\
\hline 31 & 237 & 19.58 & 4.03 & 18 & 19.8 \\
\hline 30 & 241 & 20.12 & 4.01 & 18 & 23.7 \\
\hline 42 & 284 & 20.30 & 4.03 & 18 & 60.0 \\
\hline 28 & 281 & 20.12 & 4.00 & 18 & 54.2 \\
\hline 13 & 259 & 14.30 & 2.01 & 24 & 36.0 \\
\hline 17 & 243 & 14.48 & 3.03 & 24 & 28.2 \\
\hline 43 & 281 & 14.18 & 2.99 & 24 & 57.2 \\
\hline 12 & 257 & 8.30 & 3.01 & 24 & 20.7 \\
\hline 2 & 261 & 19.88 & 3.03 & 24 & 42.7 \\
\hline 8 & 263 & 13.82 & 3.03 & 24 & 27.5 \\
\hline 1 & 259 & 14.30 & 3.00 & 24 & 25.2 \\
\hline 5 & 262 & 13.70 & 2.98 & 24 & 26.5 \\
\hline 27 & 260 & 20.36 & 4.03 & 24 & 19.1 \\
\hline 7 & 244 & 8.30 & 2.06 & 30 & 51.0 \\
\hline 4 & 240 & 8.18 & 2.01 & 30 & 47.3 \\
\hline 15 & 280 & 8.00 & 2.04 & 30 & 80.6 \\
\hline 32 & 284 & 8.42 & 2.06 & 30 & 85.9 \\
\hline 9 & 248 & 20.42 & 2.03 & 30 & 73.0 \\
\hline 18 & 242 & 19.82 & 2.00 & 30 & 70.0 \\
\hline 19 & 284 & 20.78 & 2.01 & 30 & 97.4 \\
\hline 39 & 278 & 19.88 & 2.04 & 30 & 90.0 \\
\hline 35 & 260 & 14.18 & 3.04 & 30 & 31.8 \\
\hline
\end{tabular}


Table 2. Cont.

\begin{tabular}{cccccc}
\hline $\begin{array}{c}\text { Run } \\
\text { order }\end{array}$ & $\begin{array}{c}\text { Temperature } \\
\left({ }^{\circ} \mathbf{C}\right)\end{array}$ & $\begin{array}{c}\text { Pressure } \\
(\mathbf{M P a})\end{array}$ & $\begin{array}{c}\text { Total mass flow rate } \\
(\mathbf{g} / \mathbf{m i n})\end{array}$ & $\begin{array}{c}\text { EtOH:Oil } \\
(\mathbf{m o l} \text { ratio) }\end{array}$ & $\begin{array}{c}\text { FAEE } \\
\mathbf{\%}(\mathbf{w} / \mathbf{w})\end{array}$ \\
\hline 38 & 238 & 8.48 & 4.05 & 30 & 35.0 \\
20 & 243 & 8.12 & 4.02 & 30 & 40.7 \\
33 & 278 & 8.30 & 4.03 & 30 & 59.4 \\
23 & 283 & 8.12 & 4.01 & 30 & 64.6 \\
6 & 237 & 19.82 & 4.06 & 30 & 41.2 \\
40 & 241 & 20.00 & 4.03 & 30 & 45.1 \\
22 & 279 & 20.00 & 4.01 & 30 & 50.8 \\
25 & 283 & 20.60 & 3.99 & 30 & 55.0 \\
\hline
\end{tabular}

Table 3. Analysis of variance (ANOVA) results of the full quadratic regression model.

\begin{tabular}{cccccc}
\hline Source & Sum of squares & DF & Mean square & $\boldsymbol{F}$ value & \multicolumn{1}{c}{$\boldsymbol{P}$-value } \\
\hline A & 3041.85 & 1 & 3041.85 & 60.62 & $<0.0001$ \\
B & 618.93 & 1 & 618.93 & 12.33 & 0.0015 \\
C & 4541.78 & 1 & 4541.78 & 90.52 & $<0.0001$ \\
D & 2807.72 & 1 & 2807.72 & 55.96 & $<0.0001$ \\
$\mathrm{~A}^{2}$ & 503.35 & 1 & 503.35 & 10.03 & 0.0037 \\
$\mathrm{~B}^{2}$ & 185.73 & 1 & 185.73 & 3.70 & 0.0446 \\
$\mathrm{C}^{2}$ & 72.56 & 1 & 72.56 & 1.44 & $0.2392 *$ \\
$\mathrm{D}^{2}$ & 2.09 & 1 & 2.09 & 0.04 & $0.8398 *$ \\
$\mathrm{AB}$ & 316.09 & 1 & 316.09 & 6.29 & 0.0181 \\
$\mathrm{AC}$ & 285.95 & 1 & 285.95 & 5.69 & 0.0240 \\
$\mathrm{AD}$ & 5.49 & 1 & 5.49 & 0.10 & $0.7432 *$ \\
$\mathrm{BC}$ & 187.05 & 1 & 187.05 & 3.72 & $0.0637 *$ \\
$\mathrm{BD}$ & 10.42 & 1 & 10.42 & 0.21 & $0.6520 *$ \\
CD & 46.89 & 1 & 46.89 & 0.93 & $0.3420 *$ \\
Residual & 1404.92 & 28 & 50.18 & & \\
Core Total & 19442.97 & 42 & & & \\
\hline A & & & & \\
\hline
\end{tabular}

$\mathrm{A}=$ temperature $\left({ }^{\circ} \mathrm{C}\right) ; \mathrm{B}=$ pressure $(\mathrm{MPa}) ; \mathrm{C}=$ total mass flow rate $(\mathrm{g} / \mathrm{min})$ and $\mathrm{D}=$ ethanol:oil molar ratio; * Excluded factors.

After excluding the insignificant factors (those with a p-value of more than 0.05 ) the modified quadratic model can be written as in Equation (2):

$$
\%(\mathrm{w} / \mathrm{w}) \text { FAEE }=26.95+9.82 A+4.19 B-11.63 C+9.27 D+12.65 A^{2} 12.16+B^{2}-3.11 A B+3.04 A C
$$

where $\%(\mathrm{w} / \mathrm{w})$ FAEE is the FAEE content in biodiesel product as describe in Section 2.4.

$A$ is temperature in terms of the coded unit, derived by Equation (3):

$$
A=\frac{\mathrm{T}\left({ }^{\circ} \mathrm{C}\right)-260}{20}
$$

$B$ is the pressure in terms of the coded unit, derived by Equation (4):

$$
B=\frac{\mathrm{P}(\mathrm{MPa})-14}{8}
$$


$C$ is the total mass flow rate in terms of the coded unit, derived by Equation (5):

$$
C=\frac{\text { Total mass flow rate }(\mathrm{g} / \mathrm{min})-3}{1}
$$

$D$ is the ethanol:palm oil molar ratio in terms of the coded unit, derived by Equation (6):

$$
D=\frac{\text { EtOH : oil molar ratio }-24}{6}
$$

The magnitude of the main effects (A, B, C and D) in Equation (2) demonstrated that the operating pressure (B) has the lowest influence on the $\%(w / w)$ FAEE content, which agreed well with both the results in the preliminary part of this study (Section 3.1) and those previously reported in the literature in a catalyst-free system $[7,22]$. In the catalyst-free transesterification under SCA, the temperature has been reported to be the most important factor determining the completeness of the reaction [23-25], whereas, in this study, its effect was reduced to be equal to that of the alcohol/oil molar ratio and the total mass flow rate. This is probably due to the presence of the $\mathrm{CaO}$ catalyst. Furthermore, the highest magnitude and negative effect of total mass flow rate $(C)$ illustrated that increasing the total mass flow rate dramatically decreased the $\%(w / w)$ FAEE content in the biodiesel product. In this study, the total mass flow rate was found to be the most critical parameter which needs to be optimized to evaluate the production capacity of the fixed bed reactor.

The interaction term between the temperature and pressure $(\mathrm{AB})$ is included in the regression model since the density and reactivity of ethanol are directly affected by both the operating temperature and pressure [26,27]. The minus sign of this interaction term represents the fact that a high $\%(w / w)$ FAEE content was observed when operating at a low temperature $(-1)$ and high pressure $(+1)$ or vice versa. At a low temperature, the $\mathrm{CaO}$ catalyzed the transesterification reaction with a high $\%(w / w)$ FAEE content being obtained, whereas the presence of the catalyst insignificantly enhanced the chemical kinetics when the reaction took place at the higher temperature. In addition, the interaction term between the temperature and the total flow rate (AC) reveals the implicit effect of the residence time on the resultant FAEE content. The plus sign of the AC interaction demonstrated that the \% (w/w) FAEE could be enhanced when both a high temperature $(+1)$ and a high flow rate $(+1)$ were employed, or vice versa. Since the thermal cracking of unsaturated fatty acids took place at a high temperature and long residence time, a high flow rate was required to avoid decreasing the $\%(\mathrm{w} / \mathrm{w})$ FAEE content. On the other hand, a low flow rate was necessary to achieve the complete transesterification conversion at a low temperature.

The second order effects of temperature and pressure $\left(\mathrm{A}^{2}\right.$ and $\left.\mathrm{B}^{2}\right)$ reflect that the optimal temperature and pressure are located within the experimental ranges while the optimal total mass flow rate and ethanol/palm oil molar ratio $(\mathrm{C}$ and $\mathrm{D})$ are on the edge of the experimental design. According to the sign of those coefficients, the optimal point for factors $\mathrm{C}$ and $\mathrm{D}$ were the lowest total mass flow rate $(2 \mathrm{~g} / \mathrm{min})$ and the highest ethanol/palm oil molar ratio $(30: 1)$, respectively.

The contour plot of the $\%(\mathrm{w} / \mathrm{w})$ FAEE at a total mass flow rate of $2 \mathrm{~g} / \mathrm{min}$ and an ethanol/palm oil molar ratio of 30:1, which was generated from Equation (2), is shown in Figure 7, where a FAEE content of over $96.5 \%(\mathrm{w} / \mathrm{w})$, could be found at an operating temperature above $290{ }^{\circ} \mathrm{C}$ and a pressure range of 11.0-17.0 $\mathrm{MPa}$. It should be noted that the shaded area on the contour plot represents a high predicted error of the regression model overlay on the solutions. With reference to the effect of 
residence time upon the FAEE content (see Figure 6), the FAEE content obtained was 90.8\% (w/w) at $300{ }^{\circ} \mathrm{C}$ and $20 \mathrm{MPa}$, which is located on the optimal temperature and pressure range in the regression model. Unfortunately, the FAEE content actually obtained was slightly lower than $96.5 \%$ (w/w) when a total mass flow rate of $2 \mathrm{~g} / \mathrm{min}$ was employed. In addition, small hydrocarbon compounds were detected in the obtained samples, supporting the notion that there was degradation by thermal cracking. Thus, the optimal total mass flow rate should be between 2 and $3 \mathrm{~g} / \mathrm{min}$, but this could not be experimentally verified as the high-pressure pumps could not operate precisely in the decimal range.

Figure 7. The contour plot of the $\%(w / w)$ FAEE content at various temperatures and pressures with a constant ethanol/palm oil molar ratio of 30:1 and a total mass flow rate of $2.0 \mathrm{~g} / \mathrm{min}$.

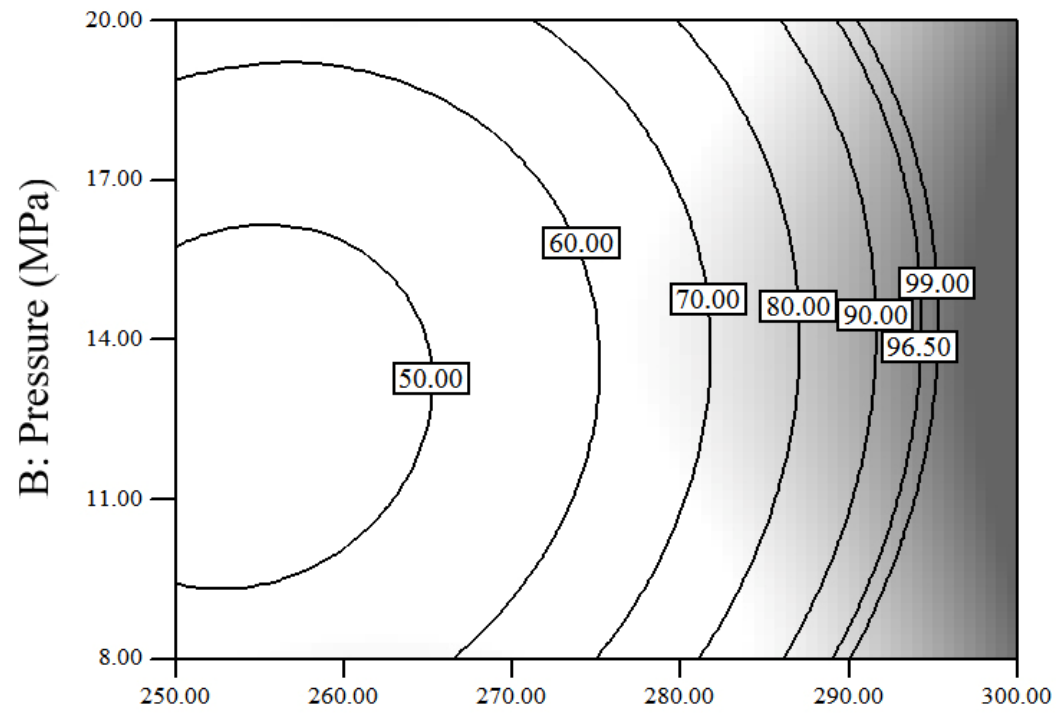

A: Temperature $\left({ }^{\circ} \mathrm{C}\right)$

On the other hand, the thermal cracking of the resultant product could be avoided by lowering the temperature. As such, the maximum FAEE content of $97.5 \%(\mathrm{w} / \mathrm{w})$ was found at $285{ }^{\circ} \mathrm{C}, 20 \mathrm{MPa}$, and a 30:1 ethanol/oil molar ratio with a total mass flow rate of $2 \mathrm{~g} / \mathrm{min}$. Under these conditions the calculated residence time was $4.85 \mathrm{~min}$. It has previously been reported that the continuous transesterification of soybean oil in a catalyst free SCE system at $300{ }^{\circ} \mathrm{C}, 20.0 \mathrm{MPa}$ and a $40: 1$ ethanol/oil molar ratio yielded an approximately 30\% (w/w) FAEE content within 60 min of residence time [28]. The drastically shortened optimal residence time of this work is due to the catalytic effects of the $\mathrm{CaO} / \mathrm{Al}_{2} \mathrm{O}_{3}$ catalyst. Furthermore, from the observed FAEE content of $52.3 \%(\mathrm{w} / \mathrm{w})$ with the inert $\mathrm{Al}_{2} \mathrm{O}_{3}$ bed but no $\mathrm{CaO}$ catalyst (see Figure 4), it is assumed that the FAEE content was also enhanced because the packed catalyst performed as a static mixer. Although data on the catalytic transesterification in SCE is presently lacking, the result from this work is comparable to the reported optimal reaction time of 8.33 min for the complete transesterification of soybean oil in $\mathrm{SCM}$ with $\mathrm{CaO}$ as catalyst in a batch reactor [15].

Only one metal oxide catalyst was so far used in this study, namely $\mathrm{CaO}$. Therefore, a comparative evaluation of $\mathrm{ZnO} / \mathrm{Al}_{2} \mathrm{O}_{3}$ and $\mathrm{La}_{2} \mathrm{O}_{3} / \mathrm{Al}_{2} \mathrm{O}_{3}$ catalysts for their activity, compared to that of $\mathrm{CaO} / \mathrm{Al}_{2} \mathrm{O}_{3}$, was performed under the same conditions, with the results summarized in Figure 8 . Note the 
conditions used were those optimized for $\mathrm{CaO} / \mathrm{Al}_{2} \mathrm{O}_{3}$ and so although the same for all three catalysts they may not be optimal for the other two catalysts. Nevertheless, the $\mathrm{La}_{2} \mathrm{O}_{3} / \mathrm{Al}_{2} \mathrm{O}_{3}$ catalyst revealed a slightly higher initial activity than that of the $\mathrm{CaO} / \mathrm{Al}_{2} \mathrm{O}_{3}$ catalyst, while the $\mathrm{ZnO} / \mathrm{Al}_{2} \mathrm{O}_{3}$ catalyst had by far the lowest activity. In other words, the $\mathrm{La}_{2} \mathrm{O}_{3} / \mathrm{Al}_{2} \mathrm{O}_{3}$ catalyst had a two-fold lower induction period than the $\mathrm{CaO} / \mathrm{Al}_{2} \mathrm{O}_{3}$ one $(30 \mathrm{~min} v s .60 \mathrm{~min}$ ). After the induction period finished, the FAEE content that was obtained from the $\mathrm{La}_{2} \mathrm{O}_{3} / \mathrm{Al}_{2} \mathrm{O}_{3}$ catalyst was nearly the same as that from the $\mathrm{CaO} / \mathrm{Al}_{2} \mathrm{O}_{3}$ catalyst over the 180 min test run. Nevertheless, the $\mathrm{CaO} / \mathrm{Al}_{2} \mathrm{O}_{3}$ catalyst is much cheaper than $\mathrm{La}_{2} \mathrm{O}_{3} / \mathrm{Al}_{2} \mathrm{O}_{3}$ catalyst, currently being 800 -fold less expensive (80 $\$ / \mathrm{kg}$ and $0.1 \$ / \mathrm{kg}$, respectively) [29]. Therefore, when comparing the technical and economic benefits together, the $\mathrm{CaO} / \mathrm{Al}_{2} \mathrm{O}_{3}$ catalyst has a higher potential than the $\mathrm{La}_{2} \mathrm{O}_{3} / \mathrm{Al}_{2} \mathrm{O}_{3}$ catalyst.

Figure 8. The $\%(w / w)$ FAEE content as function of the operating time for the SCE transesterification of palm oil at $285{ }^{\circ} \mathrm{C}, 20 \mathrm{MPa}$ and an ethanol/palm oil molar ratio of $30: 1$, a total mass flow rate of $2.0 \mathrm{~g} / \mathrm{min}$ and a residence time of $4.85 \mathrm{~min}$. Data are shown as the mean $\pm 1 \mathrm{SD}$ and are derived from two independent replicates.

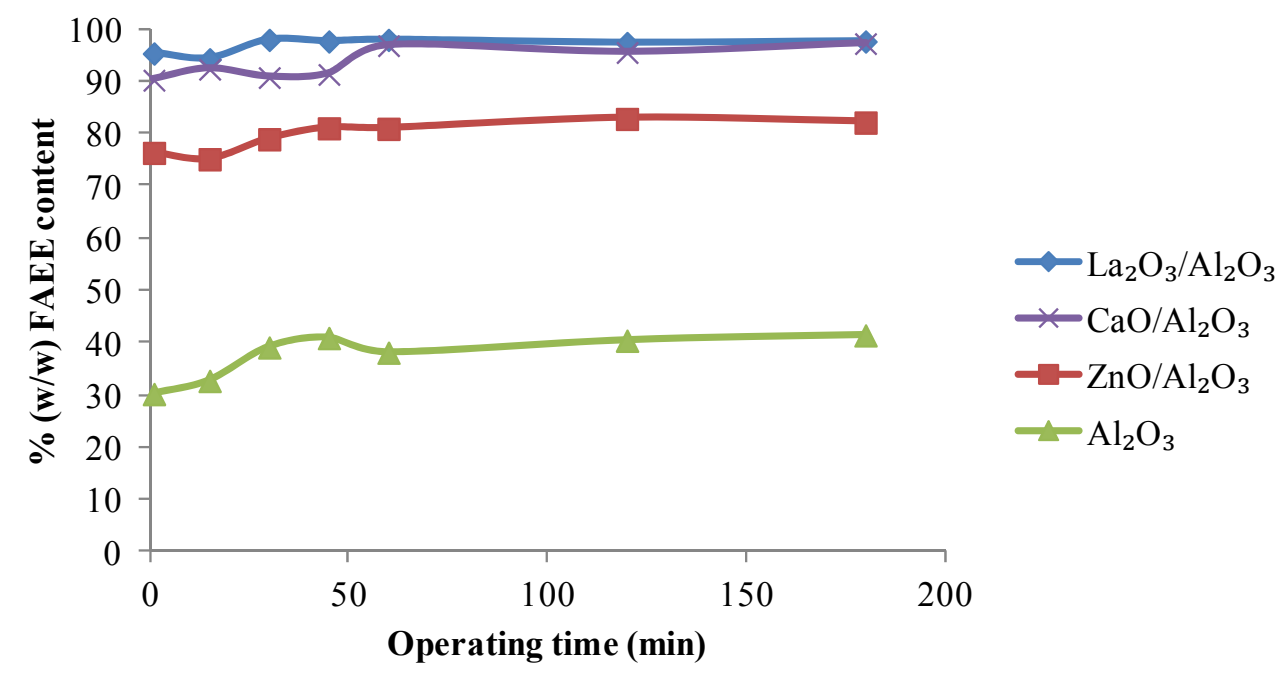

To clarify the durability test results, the $\mathrm{Al}_{2} \mathrm{O}_{3}$ support, and the unused and the used (6 and $32 \mathrm{~h}$ ) $\mathrm{CaO} / \mathrm{Al}_{2} \mathrm{O}_{3}$ and $\mathrm{La}_{2} \mathrm{O}_{3} / \mathrm{Al}_{2} \mathrm{O}_{3}$ catalysts were characterized using XRF spectrometry and XRD analyses. The active metal to aluminum ratio of the $\mathrm{CaO} / \mathrm{Al}_{2} \mathrm{O}_{3}$ catalyst remained at the same level after $6 \mathrm{~h}$ use but then decreased to $70 \%$ of the initial level at $32 \mathrm{~h}$ use, whilst that for the $\mathrm{La}_{2} \mathrm{O}_{3} / \mathrm{Al}_{2} \mathrm{O}_{3}$ catalyst remained constant after 6 and $32 \mathrm{~h}$ use. The catalytic activity of the $\mathrm{CaO} / \mathrm{Al}_{2} \mathrm{O}_{3}$ catalyst was therefore likely to have been lowered due to the leaching of the active metal cation $\left(\mathrm{Ca}^{2+}\right)$ from the surface of the catalyst. However, that the presence of calcium ions was not detected in the resultant biodiesel (data not shown) is probably simply due to the partitioning of them into the aqueous glycerol phase prior to extraction of the FAEE (biodiesel) phase.

\subsection{Fuel Properties Analysis}

The FAEE biodiesel produced under the optimal conditions $\left(285{ }^{\circ} \mathrm{C}, 20 \mathrm{MPa}, 30: 1\right.$ ethanol/oil molar ratio and $2 \mathrm{~g} / \mathrm{min}$ total mass flow rate), was subject to fuel analysis along with, for comparison, commercial FAME biodiesel samples from the PTT Research \&Technology Institute that comply with 
the International Biodiesel Standard (EN14214). The FAME sample was produced from the refined bleached deodorized palm oil using $\mathrm{NaOH}$ as the catalyst at $65{ }^{\circ} \mathrm{C}$ and atmospheric pressure. The fuel properties of the FAEE produced here and the commercial FAME samples are summarized in Table 4.

Table 4. Selected fuel properties of the FAEE biodiesel samples obtained from the optimal SCE conditions using $\mathrm{CaO} / \mathrm{Al}_{2} \mathrm{O}_{3}$ as the catalyst, compared with those of a commercial FAME biodiesel.

\begin{tabular}{cccc}
\hline Physical-Chemical Properties & \multicolumn{2}{c}{ Samples } & $\begin{array}{c}\text { Biodiesel Standard } \\
\text { Specification }\end{array}$ \\
\hline$\%(\mathrm{w} / \mathrm{w})$ ester content & FAME & FAEE & 96.5 \\
Density at $20{ }^{\circ} \mathrm{C}\left(\mathrm{kg} / \mathrm{m}^{3}\right)$ & 865 & 97.0 & $860-900$ \\
Viscosity at $40{ }^{\circ} \mathrm{C}\left(\mathrm{mm}^{2} / \mathrm{s}\right)$ & 4.1 & 883 & $3.5-5.0$ \\
Flash point $\left({ }^{\circ} \mathrm{C}\right)$ & 110.0 & 117.0 & $120(\mathrm{~min})$ \\
Cetane index & 56 & 57 & $51(\mathrm{~min})$ \\
IBP & & & \\
$50 \%$ & 187.3 & 190.2 & Take note \\
$95 \%$ & 308.2 & 310.2 & $245.0-310.0$ \\
FBP & 310.6 & 313.4 & $370.0(\max )$ \\
Pour point $\left({ }^{\circ} \mathrm{C}\right)$ & 501.1 & 503.2 & Take note \\
Acid value $(\mathrm{mg} \mathrm{KOH})$ & 11 & 6 & Take note \\
Copper corrosion & 0.12 & 0.14 & 0.50 \\
Free glycerin content $(\%)$ & $1 \mathrm{~A}$ & $1 \mathrm{~A}$ & Class $1 \mathrm{~A}(\max )$ \\
Total glycerin content $(\%)$ & $\mathrm{N} / \mathrm{D}$ & $\mathrm{N} / \mathrm{D}$ & $0.02(\max )$ \\
& 0.11 & 0.18 & $0.25(\max )$ \\
\hline
\end{tabular}

$\mathrm{N} / \mathrm{D}$ is not detected.

The evaluated fuel properties of both the FAEE produced in this study, and the commercial reference FAME biodiesel samples met all specification values, except for a slightly low flash point in the FAEE $\left(117 v s .120{ }^{\circ} \mathrm{C}\right)$, which was even lower in the commercial FAME samples $\left(110{ }^{\circ} \mathrm{C}\right)$. The $\%$ ester content in the FAEE product of $97.0 \%(\mathrm{w} / \mathrm{w})$ was slightly higher than the specification value of 96.5\% (w/w), while the density and viscosity of the FAEE samples were near the upper limits. Comparing the FAEE and FAME samples, the density, viscosity and flash point of the FAEE samples were slightly higher, while the pour point was lower, than those of FAME samples. This will simply be due to the difference between the methyl and ethyl groups in the resultant biodiesel [30].

When operating at the traditional operating parameters, for instance, at $350{ }^{\circ} \mathrm{C}, 20 \mathrm{MPa}$ and $42: 1$ methanol to oil molar ratio, the production cost of SCM as reported in the literature is higher than that of conventional method [31]. However, it could be half that of the conventional method if those parameters are lowered by some assisting techniques, such as the addition of co-solvents and catalysts [32,33]. The lowered parameters are approximately located among a temperature of 270-300 ${ }^{\circ} \mathrm{C}$, pressure of 10-15 MPa and methanol to oil molar ratio of 1:20-1:30. It should be noted that all parameters are not reduced at the same time to maintain the highest ester conversion. In the case of SCE, although economic studies are presently scarce, it could be deduced that the production cost is reduced due to the addition of $\mathrm{CaO} / \mathrm{Al}_{2} \mathrm{O}_{3}$ as the heterogeneous catalyst. 
According to the production performance, the conventional homogeneous catalytic process cannot directly use high water and/or free fatty acids containing feedstocks but the SCE process is capable [7,22]. Even though the conventional process operates under atmospheric pressure, it generates a significant amount of waste and requires a long production time because the product washing step. Therefore, the SCE process is likely to have a better production performance than the conventional process when considering the feedstock flexibility and environmental impacts altogether, especially for use of hydrated ethanol as feedstock.

\section{Conclusions}

The transesterification of palm oil and hydrated ethanol by SCE in a fixed bed reactor with $\mathrm{CaO} / \mathrm{Al}_{2} \mathrm{O}_{3}$ as the heterogeneous catalyst was successfully achieved and optimized using RSM. The optimal conditions in this laboratory experimental scale reactor were $285^{\circ} \mathrm{C}, 20 \mathrm{MPa}$, an ethanol/oil molar ratio of 30:1, a total mass flow rate of $2 \mathrm{~g} / \mathrm{min}$ and a residence time of $4.85 \mathrm{~min}$. Because of the small volume of this lab scale reactor, approximately $30 \mathrm{~cm}^{3}$, the optimal flow rate for the suitable residence time that simultaneously avoids thermal cracking of product and obtains the highest FAEE content was found at $2 \mathrm{~g} / \mathrm{min}$. However, the production rate could be enhanced by increasing the reactor volume and this requires to be confirmed and optimized in further studies. The resultant FAEE biodiesel obtained under these optimal conditions had a 97\% (w/w) FAEE content and complied with the International Biodiesel Standard (EN14214). The $\mathrm{La}_{2} \mathrm{O}_{3} / \mathrm{Al}_{2} \mathrm{O}_{3}$ catalyst displayed a slightly higher initial activity and had a potentially greater durability than that of the $\mathrm{CaO} / \mathrm{Al}_{2} \mathrm{O}_{3}$ one, but the price of $\mathrm{La}_{2} \mathrm{O}_{3}$ is dramatically higher (currently 800 -fold) than that for $\mathrm{CaO}$. Thus, the $\mathrm{CaO} / \mathrm{Al}_{2} \mathrm{O}_{3}$ catalyst is a promising catalyst for biodiesel production using hydrated ethanol as a feedstock, when comparing the technical and economic benefits together.

\section{Acknowledgments}

The authors would like to acknowledge the financial support from the Postdoctoral Fellowship (Ratchadaphiseksomphot Endowment Fund) and the Thai Government Stimulus Package 2 (TKK2555), under the Project for Establishment of Comprehensive Center for Innovative Food, Health Products and Agriculture. The authors also express their sincere appreciation to the PTT Research Institute for provision of the FAME biodiesel samples and the fuel testing laboratory in the quality control division of PTT public company limited for the fuel testing apparatus. The authors also wish to express their thanks to Robert Douglas John Butcher (Publication Counseling Unit, Faculty of Science, Chulalongkorn University) for English language editing.

\section{References}

1. Pinnarat, T.; Savage, P.E. Assessment of noncatalytic biodiesel synthesis using supercritical reaction conditions. Ind. Eng. Chem. Res. 2008, 47, 6801-6808.

2. Sawangkeaw, R.; Bunyakiat, K.; Ngamprasertsith, S. A review of laboratory-scale research on lipid conversion to biodiesel with supercritical methanol (2001-2009). J. Supercrit. Fluids 2010, $55,1-13$. 
3. Lee, J.S.; Saka, S. Biodiesel production by heterogeneous catalysts and supercritical technologies. Bioresour. Technol. 2010, 101, 7191-7200.

4. Juan, J.C.; Kartika, D.A.; Wu, T.Y.; Hin, T.Y.Y. Biodiesel production from Jatropha oil by catalytic and non-catalytic approaches: An overview. Bioresour. Technol. 2010, 102, 452-460.

5. De Boer, K.; Bahri, P.A. Supercritical methanol for fatty acid methyl ester production: A review. Biomass Bioenergy 2011, 35, 983-991.

6. Trentin, C.M.; Lima, A.P.; Alkimim, I.P.; da Silva, C.; de Castilhos, F.; Mazutti, M.A.; Oliveira, J.V. Continuous catalyst-free production of fatty acid ethyl esters from soybean oil in microtube reactor using supercritical carbon dioxide as co-solvent. J. Supercrit. Fluids 2011, 56, 283-291.

7. Vieitez, I.; Pardo, M.J.; da Silva, C.; Bertoldi, C.; de Castilhos, F.; Oliveira, J.V.; Grompone, M.A.; Jachmanián, I. Continuous synthesis of castor oil ethyl esters under supercritical ethanol. J. Supercrit. Fluids 2011, 56, 271-276.

8. Saka, S.; Kusdiana, D. Biodiesel fuel from rapeseed oil as prepared in supercritical methanol. Fuel 2001, 80, 225-231.

9. Kusdiana, D.; Saka, S. Kinetics of transesterification in rapeseed oil to biodiesel fuel as treated in supercritical methanol. Fuel 2001, 80, 693-698.

10. Demirbas, A. Biodiesel from vegetable oils via transesterification in supercritical methanol. Energy Convers. Manag. 2002, 43, 2349-2356.

11. Boey, P.L.; Maniam, G.P.; Hamid, S.A. Performance of calcium oxide as a heterogeneous catalyst in biodiesel production: A review. Chem. Eng. J. 2011, 168, 15-22.

12. Zabeti, M.; Daud, W.M.A.W.; Aroua, M.K. Biodiesel production using alumina-supported calcium oxide: An optimization study. Fuel Process. Technol. 2010, 91, 243-248.

13. Kouzu, M.; Kasuno, T.; Tajika, M.; Sugimoto, Y.; Yamanaka, S.; Hidaka, J. Calcium oxide as a solid base catalyst for transesterification of soybean oil and its application to biodiesel production. Fuel 2008, 87, 2798-2806.

14. Ngamcharussrivichai, C.; Nunthasanti, P.; Tanachai, S.; Bunyakiat, K. Biodiesel production through transesterification over natural calciums. Fuel Process. Technol. 2010, 91, 1409-1415.

15. Demirbas, A. Biodiesel from sunflower oil in supercritical methanol with calcium oxide. Energy Convers. Manag. 2007, 48, 937-941.

16. Montgomery, C.D. Design and Analysis of Experiments, 7th ed.; John Wiley and Sons: New York, NY, USA, 2010; p. 428.

17. Box, G.E.P.; Hunter, J.S.; Hunter, W.G. Statistics for Experimenters: Design, Innovation and Discovery, 2nd ed.; Wiley-Interscience: New Jersey, NJ, USA, 2005; pp. 450-451.

18. Abdurashidova, A.; Bazaev, A.; Bazaev, E.; Abdulagatov, I. The thermal properties of water-ethanol system in the near-critical and supercritical states. High Temp. 2007, 45, 178-186.

19. Anand, K.; Ranjan, A.; Mehta, P.S. Predicting the density of straight and processed vegetable Oils from fatty acid composition. Energy Fuels 2010, 24, 3262-3266.

20. Xu, J.; Jiang, J.; Chen, J.; Sun, Y. Biofuel production from catalytic cracking of woody oils. Bioresour. Technol. 2010, 101, 5586-5591.

21. Megahed, O.; Abdelmonem, N.; Nabil, D. Thermal cracking of rapeseed oil as alternative fuel. Energy Sources Part A 2004, 26, 1033-1042. 
22. Vieitez, I.; da Silva, C.; Borges, G.R.; Corazza, F.C.; Oliveira, J.V.; Grompone, M.A.; Jachmanian, I. Continuous production of soybean biodiesel in supercritical ethanol/water mixtures. Energy Fuels 2008, 22, 2805-2809.

23. Bunyakiat, K.; Makmee, S.; Sawangkeaw, R.; Ngamprasertsith, S. Continuous production of biodiesel via transesterification from vegetable oils in supercritical methanol. Energy Fuels 2006, 20, 812-817.

24. Song, E.S.; Lim, J.W.; Lee, H.S.; Lee, Y.W. Transesterification of RBD palm oil using supercritical methanol. J. Supercrit. Fluids 2008, 44, 356-363.

25. Gui, M.M.; Lee, K.T.; Bhatia, S. Supercritical ethanol technology for the production of biodiesel: Process optimization studies. J. Supercrit. Fluids 2009, 49, 286-292.

26. Hoffmann, M.M.; Conradi, M.S. Are there hydrogen bonds in supercritical methanol and ethanol? J. Phys. Chem. B 1998, 102, 263-271.

27. Velez, A.; Hegel, P.; Mabe, G.; Brignole, E.A. Density and conversion in biodiesel production with supercritical methanol. Ind. Eng. Chem. Res. 2010, 49, 7666-7670.

28. Bertoldi, C.; da Silva, C.; Bernardon, J.P.; Corazza, M.L.; Filho, L.C.; Oliveira, J.V.; Corazza, F.C. Continuous production of biodiesel from soybean oil in supercritical ethanol and carbon dioxide as cosolvent. Energy Fuels 2009, 23, 5165-5172.

29. Chemicalland 21 Homepage. Available online: http://chemicalland21.com (accessed on 6 January 2012).

30. Knothe, G. Dependence of biodiesel fuel properties on the structure of fatty acid alkyl esters. Fuel Process. Technol. 2005, 86, 1059-1070.

31. Marchetti, J.M.; Errazu, A.F. Technoeconomic study of supercritical biodiesel production plant. Energy Convers. Manag. 2008, 49, 2160-2164.

32. Diaz, M.S.; Espinosa, S.; Brignole, E.A. Model-Based cost minimization in noncatalytic biodiesel production plants. Energy Fuels 2009, 23, 5587-5595.

33. Deshpande, A.; Anitescu, G.; Rice, P.A.; Tavlarides, L.L. Supercritical biodiesel production and power cogeneration: Technical and economic feasibilities. Bioresour. Technol. 2010, 101, $1834-1843$.

(C) 2012 by the authors; licensee MDPI, Basel, Switzerland. This article is an open access article distributed under the terms and conditions of the Creative Commons Attribution license (http://creativecommons.org/licenses/by/3.0/). 